\title{
Perspectives on the use of geothermal heat pump systems to reduce low emitted air pollutants in the health resort areas
}

\author{
Aleksandra Szulc ${ }^{1, *}$, and Barbara Tomaszewska ${ }^{1}$ \\ ${ }^{1}$ AGH University of Science and Technology, Faculty of Geology, Geophysics and Environmental \\ Protection, Al. Mickiewicza 30, 30-059 Kraków, Poland
}

\begin{abstract}
The paper presents the possibilities of using geothermal heat pump systems in order to reduce the so-called "low-emission" in health resort area. The analysis was carried out on the example of the health resort Rabka-Zdrój, located in the southern part of Poland. Based on the acquired geological profiles of the boreholes, a detailed analysis of the rock mass was made in terms of thermal parameters. An interpretation of the potential unit heat output from individual boreholes was also made and the total lengths of vertical heat exchangers were determined for them. It was found that the health resort area has good thermal parameters of the rock mass, which can be used in shallow geothermal systems. Thermal conductivity coefficients $(\lambda)$ of boreholes are in the range of $1.59-3.42[\mathrm{~W} /(\mathrm{m} \cdot \mathrm{K})]$. In addition, the value of the $\lambda$ coefficient below $2.0[\mathrm{~W} /(\mathrm{m} \cdot \mathrm{K})]$ was recorded in two cases. It was emphasized that the use of geothermal heat pump systems can have a significant contribution to reducing emission of pollutants and contribute to the reduction of so-called "low-emission". The obtained values of the ecological effect in relation to coal-fired boilers limit by $99 \%$ the dust emission and $\mathrm{B}(\mathrm{a}) \mathrm{P}$, which are the dominant pollutants in the context of so-called "low-emissions".
\end{abstract}

\section{Introduction}

Nowadays, the major part of the world energy system is based on fossil fuels. In fact, this situation is increasingly influencing the climate, natural environment and human health. Since 2000, global $\mathrm{CO}_{2}$ emissions have increased by around $40 \%$ and today achieve the level of $32 \mathrm{GtCO}_{2}$ [1]. Furthermore, air pollutions (e.g. $\mathrm{PM}_{10}, \mathrm{PM}_{2.5}, \mathrm{BaP}, \mathrm{NO}_{\mathrm{x}}, \mathrm{O}_{3}$ ) pose a significant problem for urban agglomerations, small towns let alone the villages worldwide. The report published in 2016 by World Health Organization (WHO) presents that about $90 \%$ of the world population breaths polluted air which does not comply with the WHO Air Quality Guidelines (AQG). Moreover, in all regions of the world outdoor air pollution kills about 3 million people annually. The highest population exposure to particulate matter (PM10, PM2.5) occurs in South-East Asia, Western Pacific and Eastern Mediterranean Regions [2]. In recent years, emissions of primary pollutants $\left(\mathrm{PM}_{10}, \mathrm{PM}_{2.5}\right.$,

\footnotetext{
*Corresponding author: aszulc@agh.edu.pl
} 
$\mathrm{NO}_{x}, \mathrm{SO}_{\mathrm{x}}, \mathrm{BaP}, \mathrm{CO}, \mathrm{O}_{3}$ ) in Europe have decreased [3]. Despite the fact that poor air quality occurs across many areas of Europe. Poland is one of the European Union Members struggling with the so-called "low-emission" problem. In Poland "low-emission" is defined as air pollutants produced by combustion of solid, liquid and gaseous fuels, from emission sources not exceeding 40 meters above the ground. The occurrence of the "low-emission" is strictly dependent on type and quality of combusted fuels, topographical and meteorological conditions, used combustion equipment and technologies. The phenomenon of so-called "low-emission" also affects the health resort areas. In Poland the health resort municipalities are obliged to have local climate with healing properties [4] which has become a big challenge in the face of poor state of air quality in the country. Therefore, the major aim of this paper is to assess the possibilities of reducing low emission in health resort protection zones by the use of geothermal (ground-source) heat pump systems. China is an example of a country using heat pump systems in the fight against low emission especially in areas where the use of fossil fuels negatively affected the environment [5]. The areas of Beijing, Tianjin, Hebei, strongly affected by the negative effects of using coal boilers as the primary source of heat, in the coming years want to completely replace them with sources of clean energy [6]. In Europe, the basic and the most important document regulating the introduction and development in the sector of renewable energy sources is Directive 2009/28/EC of the European Parliament and of the Council of 23 April 2009 on the promotion of the use of energy from renewable sources and amending and subsequently repealing Directives 2001/77/EC and 2003/30/EC [7]. The main purpose of the Directive is to promote renewable energy sources, increase energy savings and its efficient use, thus limiting greenhouse gas emissions. Directive 2009/28/EC is an integral part of the climate and energy package until 2020, which assumes:

1) the increase in the share of energy from renewable sources to $20 \%$ of total energy consumption in the EU;

2) the improvement of energy efficiency by $20 \%$;

3 ) the reduction of greenhouse gas emissions by $20 \%$, compared to the level achieved in 1990 .

The use of large-scale heat pump technology can make a significant contribution to achieving these goals. Currently, ground source heat pumps are one of the most popular direct use of geothermal energy. This technology uses the natural heat of the earth stored in ground or bedrock to provide heating, cooling and domestic hot water for buildings. The main advantages of shallow geothermal system are: the availability of these resources around the world and stable resource of energy. In addition, the use of ground source heat pumps increasingly becomes an alternative source of energy for heating systems based on fossil fuels. Direct use of geothermal heat pumps have grown by $17 \%$ over the last 10 years $[8,9]$. Most of geothermal heat pump systems occur in the United States, Sweden, Finland, Norway, Switzerland and Canada [9]. According to Lund and Boyd [10] geothermal heat pumps represent respectively $55.3 \%$ and $70.9 \%$ of the worldwide installed capacity and energy use. In 2015 the annual energy use is $326.8 \mathrm{TJ} /$ year and the installed capacity is $50.3 \mathrm{MWt}$ [10]. For this paper it is important to mention that the market of heat pumps in Poland is in the initial phase of development. However, in 2017, the total sales of heat pumps have almost tripled in the previous 7 years [11]. According to the Polish Association for Heat Pump Technology and Development (PORT PC - in polish: Polska Organizacja Rozwoju Technologii Pomp Ciepła) in 2017, about 84.000 heat pumps were used in central heating installations. In turn, their share in newly built detached houses reached the level of $12.5 \%$, while in other EU countries it was about: $90 \%$ in Sweden, 33\% in Germany and $80 \%$ in Austria, respectively. The largest share on the Polish market are air-source heat pumps - about $60 \%$ and ground-source heat pumps $-38 \%$ for space heating [11]. 


\section{Materials and methods}

\subsection{Study area}

Rabka-Zdrój is one of the most popular mountain health resort in Poland. The municipality is located in the western part of the Outer Carpathians in the Rabczańska Valley at the height of 500-560 m a.s.l. The Rabczańska Valley it is surrounded by mountain ranges with the range of altitude $800-1000 \mathrm{~m}$ a.s.l. The south-eastern side the valley is surrounded by The Gorce Mountains from the north side The Island Beskids. This area is famous for the occurrence of chloride medical waters, which are commonly used in therapeutic treatments. The mineralization of curative waters of the health resort varies between 17 and $24 \mathrm{~g} / \mathrm{dm}^{3}$ [12]. Currently, healing waters in Rabka-Zdrój are exploited by the use of 9 boreholes (Bolesław, Helena, Krakus, Rafael, Warzelnia, Rabka 18, Rabka 19, Rabka IG-1 and Rabka IG-2). The climate of Rabka-Zdrój is formed mostly by the inflowing polar continental and polar maritime air masses. The average annual air temperature is $6.3^{\circ} \mathrm{C}-$ the lowest average monthly air temperature is in January $\left(-2.9^{\circ} \mathrm{C}\right)$ and the highest in July $\left(16.2^{\circ} \mathrm{C}\right)$ [13]. The location of the town in Rabka Valley is a natural barrier for strong winds. Weak winds $<2 \mathrm{~m} / \mathrm{s}$ dominate on the area of the health resort. The average annual wind speed is $1.1 \mathrm{~m} / \mathrm{s}$, while mean sum of rainfall is $864 \mathrm{~mm}$. In the period 1971-2000, the average annual sum of global solar radiation for Rabka-Zdrój was $3600 \mathrm{MJ} / \mathrm{m}^{2}$ [14]. On the other hand, the average annual total of hours with the sun for the area of Rabka-Zdrój is 1494 hours [15].

\subsection{Geology}

The research area is characterized by a complex geological structure, whose detailed recognition was enabled by deep exploration drillings. Rabka-Zdrój is located in the Western Outer Carpathians within the Magura Nappe. Differentiation of the Magura Nappe in the area of Rabka-Zdrój contributed to the separation of the three zones of tectonic facies: 1) in the northern region - the Rača zone; 2) in the central region - the Bystrica zone; 3) in the southern region - the Krynica zone [16]. The Rača zone is formed by variegated shales (the Paleocene), shales and thin-bedded sandstones (the Middle Eocene) and thick-bedded sandstones with conglomerate intercalations (the Upper Eocene) [17]. The Bystrica zone is dominated by the thin- and medium-bedded sandstones and shales (Fig. 1). In its flysch deposits there were mineral waters within the Łącko and Beloveza Beds (in seven boreholes: Warzelnia, Krakus, Helena, Rafael, Bolesław, Rabka-19, Rabka IG 1) [18]. In the surface layers of the Krynica zone there is a domination of sandstones predominantly with thick-bedded Upper Eocene sandstones [19]. In the zone profile there are also sandstones from Piwniczna with conglomerate intercalations and variegated shales as well as sandstone and slate deposits - Inoceramian Beds (the Paleocene). In addition, deep drilling in the area of Rabka (Rabka IG 1 and Rabka IG-2) allowed to document Cretaceous-Paleogene deposits, lower tectonic units defined as Grybów Unit and Dukla Obidowa-Słopnice Unit (Fig. 1) [20]. The youngest sediments located on the area of Rabka-Zdrój are quaternary deposits. They have diversified thickness and cover older folded tertiary deposits. These are mainly sediments of river origin: 1) the Pleistocene: gravels, sands and erosion-accumulation terrace river clays, loess-like and deluvial clays and clays with rock rubble; 2) the Holocene: gravels, sands and the aggregate mud of flood terraces and riverbeds as well as peats [20]. 


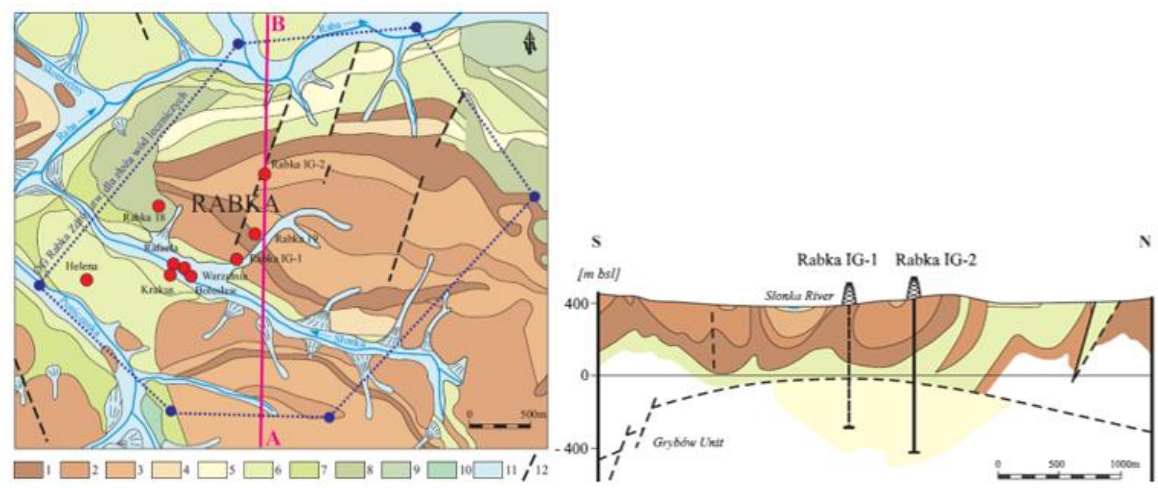

Fig. 1. Geological map and geological cross-section A-B of the Rabka-Zdrój [21]. Symbols: 1 - variegated shales with insets of coarse-bedded sandstones, 2 - marls, sandstones and shales Łącko Beds, 3 - shales and thin-bedded sandstones-Beloweza Beds, 4 - coarse-bedded sandstones within variegated shales, 5 - variegated shales of the Upper Cretaceous, 6 - medium-bedded sandstones and shales-Ropianka (Inoceramus) Beds, 7-11 - gravels, sands, loams-Quaternary, 12 - fault.

\subsection{Data analysis}

In order to evaluate the possibility of using thermal properties of the soil-rock environment in low enthalpy geothermal systems in the health resort area the archival borehole data located in Central Geological Database (CGD) and Central Hydrogeological Database (CHD) were collected. To identify geological conditions occurring in the area of Rabka-Zdrój, 26 geological profiles of boreholes were analysed along with their hydrogeological conditions. The depth of boreholes varies between 19 and $5.101 \mathrm{~m}$ below the ground level with the vast majority $-73 \%$ not exceeding the depth of $200 \mathrm{~m}$. In the area of the rural commune there are only two boreholes: Chabówka 1, Obidowa IG-1 (deep research boreholes), the others are located within the city. The rock mass of 25 boreholes with the depth not exceeding $100 \mathrm{~m}$ below the ground level has been analysed in detail. In heat pump installations based on vertical heat exchangers, the basic source of energy is the Earth's heat flow. According to the map developed by Szewczyk and Gientka the heat flow density for Rabka-Zdrój ranks at $70 \mathrm{~mW} / \mathrm{m}^{2}$ [22]. Soil temperature, within the so-called the neutral layer (the soil layer to a depth of approx. 15-20 m, in which seasonal changes in temperature are observed) is close to the average annual air temperature and is subject to daily and annual fluctuations [23-25]. The ground temperature at the depth of $0.5 \mathrm{~m}$ below the ground level within the health resort area is in the range of about $8^{\circ} \mathrm{C}$ [26]. Accurate and thorough determination of the geological and hydrogeological diversity of the soil at various depths is of great importance for setting the estimated values of the basic thermal parameter of the rock mass, which is thermal conductivity $\lambda[\mathrm{W} /(\mathrm{m} \cdot \mathrm{K})]$ [27]. The analysis involved the selection of vertical ground heat exchangers for heat pumps with a heating power $\leq 30 \mathrm{~kW}$, commonly used in households around the world [28]. The values of thermal conductivity coefficients for particular divisions in lithological profiles of the analysed boreholes were selected in accordance with the guidelines developed by Lachman et al. [28]. For each borehole, the average weighted thermal conductivity coefficient was determined, which in the subsequently will allow to determine the unit heat output of the borehole and to determine the maximum amount of heat that can safely be collected from the ground during the year. On the example of two boreholes with different heat conduction parameters, the unit heat output $[\mathrm{W} / \mathrm{m}]$ and the total power consumption from the borehole 
[W] were determined in accordance with the PORT PC guidelines. In order to determine the number of boreholes and their depths, the thermal load of a single-family building with an area of approx. $220 \mathrm{~m}^{2}$, which amounted to $8.76 \mathrm{~kW}$. After taking into account the energy additive for domestic hot water produced for 4 people, a final heat demand of $9.76 \mathrm{~kW}$ was obtained. For further calculations, the parameters for a brine/water heat pump will be used, i.e. heating power: $9.7 \mathrm{~kW}$, cooling power $7.6 \mathrm{~kW}$ for Seasonal Coefficient of Performance (SCOP) equal to 3.58 [29, 30]. The value of total annual demand for the heating purpose of the analysed building was calculated by using 'Audytor OZC' software by taking into account additive for domestic hot water produced for 4 people. Therefore, the total annual demand for heat amounted to $89 \mathrm{GJ}$, and the energy consumption for the heat pump reached the value of $6.879 \mathrm{kWh} / \mathrm{year}$. In order to compare the pollutant emission of a coal-fired boiler and heat pumps, emission factors developed by Pająk [31] were used. According to the published materials, the net calorific value for coal was $25 \mathrm{GJ} / \mathrm{Mg}$, ash content $18 \%$, sulphur content $0.8 \%$ and boiler efficiency at the level of $70 \%$. In the case of the indicator for grid hard coal energy, the values of $24.4 \mathrm{GJ} / \mathrm{Mg}, 20 \%$ and $0.8 \%$ were assumed, and additionally the efficiency of conversion of chemical energy contained in fuel into electricity taking into account the transmission loss of $31 \%$, efficiency of dust extraction $-99 \%$.

\section{Results and discussion}

A detailed analysis of geological profiles showed that in the area of Rabka-Zdrój one can distinguish several lithological complexes, i.e. sandy gravels, sandstones and shales, marls, sandstones and clays. Some of them are shown in Fig. 2, in which the geological profile of the Rabka 18 borehole to a depth of $100 \mathrm{~m}$ below the ground level has been shown. Moreover, an appropriate thermal conductivity coefficient has been assigned to each rock mass layer, the values of which vary between $0.4-5.1[\mathrm{~W} /(\mathrm{m} \cdot \mathrm{K})]$ - depending on the type of soil and the degree of water accumulation. The heat conduction coefficient recommended by PORT PC was adopted for non-water-logged rock mass layers, while the maximum values were assumed for the water-logged layers [28]. The calculated average weighted thermal conductivity coefficient for the entire borehole is $2.23[\mathrm{~W} /(\mathrm{m} \cdot \mathrm{K})]$. The remaining boreholes were analysed in the same way. The distribution of average weighted thermal conduction coefficients in the boreholes on the area of Rabka-Zdrój is shown on the map in Fig. 3. The boreholes with at least two water-logged layers are marked by the highest coefficient, especially due to the fact that they are sandstones. From the analysis it can be concluded that the more water-logged layers with high thickness, the better conduction parameters of the soil are. In the health resort area there are eight boreholes in which the $\lambda$ coefficient reached a value above $2.5[\mathrm{~W} /(\mathrm{m} \cdot \mathrm{K})]$. In addition, the higher values of $\lambda$ coefficient also determine higher unit heat output of the borehole $[\mathrm{W} / \mathrm{m}]$, and thus also the total power consumption possible to obtain from the borehole. This parameter is directly reflected in the length of the vertical heat exchanger. For holes with high power consumption, both the depth of the boreholes and their number will, in most cases, be smaller. To illustrate these relationships, two boreholes with a relatively high and low conduction coefficient were compared. Both boreholes have reached a depth of $100 \mathrm{~m}$ below the ground level. The total power consumption of the Rabka Bolesław borehole is almost $30 \%$ higher than in the case of the Rabka XIII borehole (Table 1). In addition, to meet the heat demand of the analysed building, the total length of the heat exchanger must exceed $57 \mathrm{~m}$. In the case of RABKA XIII boreholes, it has been proposed to use horizontal heat exchangers up to a depth of $100 \mathrm{~m}$. This solution was chosen due to the legal requirements regarding boreholes in Poland. According to the Geological and Mining Law, 
when drilling boreholes to a depth of $100 \mathrm{~m}$ (outside the mining area), a geological work plan is required, while there is no obligation to create a mining plant operation plan [33]. However, the other analysed borehole is located within the mining area, which requiring a mining plant operation plan for boreholes with a depth of more than $30 \mathrm{~m}$. In such a case, two solutions can be applied: 1) drilling five boreholes up to a depth of $30 \mathrm{~m}$ without the need provide a plan, or 2) drilling two 71-meter deep boreholes with the need to implement the required plan.

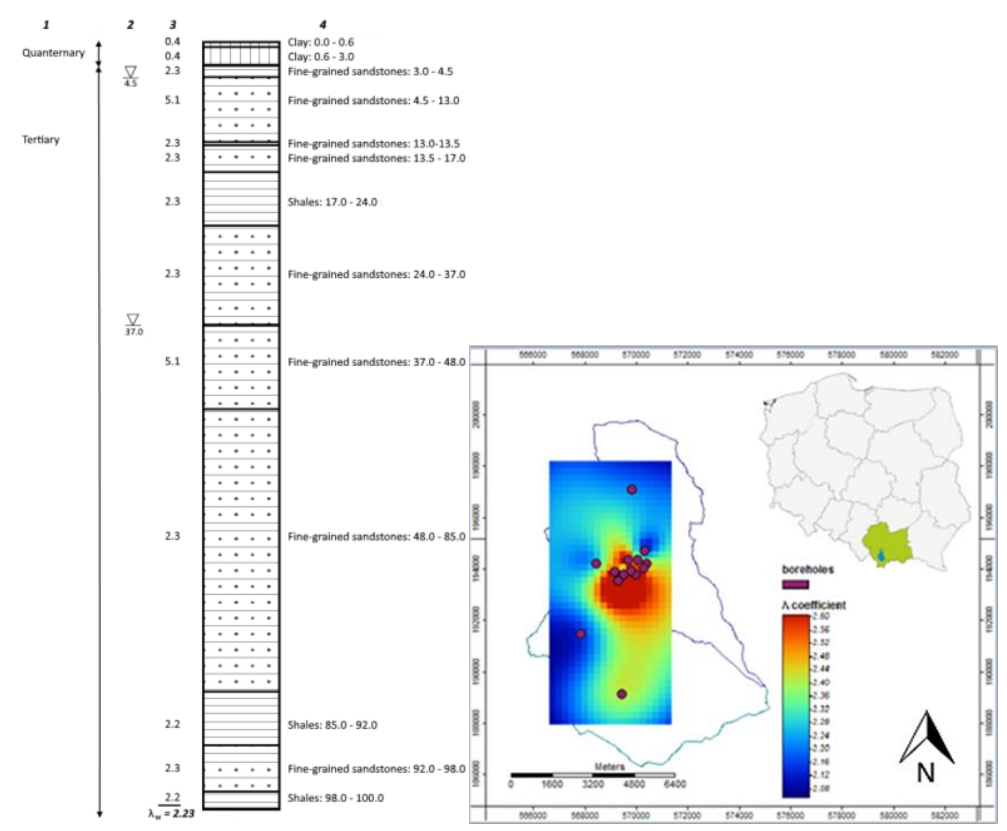

Fig. 2. Map of the distribution of thermal conductivity and geological profile of the Rabka-18 borehole with assigned thermal conductivity coefficients [based on 32]. Symbols: 1 - Stratigraphy; $\mathbf{2}$ - Water table $; \mathbf{3}$ - Thermal conductivity coefficient $[\mathrm{W} /(\mathrm{m} \cdot \mathrm{K})] ; \mathbf{4}$ - Lithology and depth [m below the ground level]; $\lambda_{w}-$ Weighted average thermal conductivity coefficient $[\mathrm{W} /(\mathrm{m} \cdot \mathrm{K})]$.

Table 1. Selection of length of the heat exchanger.

\begin{tabular}{|c|c|c|c|c|c|c|}
\hline Borehole & $\begin{array}{c}\text { Weighted } \\
\text { average } \\
\text { coefficient } \\
{[\mathbf{W} /(\mathbf{m} \cdot \mathbf{K})]}\end{array}$ & $\begin{array}{c}\text { Unit } \\
\text { heat } \\
\text { output } \\
{[\mathbf{W}]}\end{array}$ & $\begin{array}{c}\text { Total } \\
\text { power } \\
\text { consumptio } \\
\text { n of the } \\
\text { borehole } \\
{[\mathbf{W} / \mathbf{m}]}\end{array}$ & $\begin{array}{c}\text { Length of } \\
\text { the heat } \\
\text { exchanger } \\
{[\mathbf{m}]}\end{array}$ & \multicolumn{2}{|c|}{$\begin{array}{c}\text { Suggested number } \\
\text { and length of } \\
\text { exchangers }\end{array}$} \\
\hline RABKA 18 & 1.65 & 38.5 & 38500 & 197.7 & \multicolumn{2}{|c|}{$2-$ length $99 \mathrm{~m}$} \\
\hline RABKA & 3.42 & 54.0 & 54000 & 140.9 & $\begin{array}{c}5 \text { (length } \\
29 \mathrm{~m})\end{array}$ & $\begin{array}{c}2 \text { (length } \\
71 \mathrm{~m})\end{array}$ \\
\hline
\end{tabular}

Geothermal heat pumps use renewable energy stored in the soil. However, they need electricity for their work, which in Poland's case comes mainly from conventional coalbased power plants. Therefore, heat pumps cannot be considered as emission-free renewable energy devices. It was decided to compare the amount of pollutant emissions generated by the coal-fired boiler and the heat pump for the same input parameters given in subsection 2.3. When comparing the emission values for the coal boiler and the heat pump, it was found that the solution based on electricity from the grid brings the expected result an ecological effect in relation to coal (except $\left.\mathrm{NO}_{2}\right)$ (Table 2$)$. In the case of the occurrence 
of so-called "low-emission" in the air, harmful substances appear, among which dust, B(a)P or polycyclic aromatic hydrocarbons $(\mathrm{PAH})$ predominate, negatively affecting human health. From the obtained results, it can be observed that in the case of using a rock mass as a source of heat, dust emission and B(a)P can be reduced by approximately $99 \%$. A similar relationship applies to $\mathrm{CO}$ and $\mathrm{PAH}$ emissions, which can be limited to $97 \%, \mathrm{CO}_{2}$ to $24 \%$ and $\mathrm{SO}_{2}$ to $32 \%$. A preliminary analysis showed that heat pumps can significantly contribute to reduce so-called "low-emission".

Table 2. Ecological effect [kg/year] obtained for the coal boiler and heat pump.

\begin{tabular}{|c|c|c|c|c|}
\hline \multirow{2}{*}{ Pollutants } & \multicolumn{2}{|c|}{$\begin{array}{c}\text { Hard coal - coal } \\
\text { boiler }\end{array}$} & \multicolumn{2}{c|}{$\begin{array}{c}\text { Grid energy - heat } \\
\text { pump }\end{array}$} \\
\cline { 2 - 5 } & $\begin{array}{c}\text { Emission } \\
\text { factor } \\
{[\mathbf{k g} / \mathbf{G J}]^{*}}\end{array}$ & $\begin{array}{c}\text { Emission } \\
\text { unit } \\
{[\mathbf{k g} / \text { year] }}\end{array}$ & $\begin{array}{c}\text { Emission } \\
\text { factor } \\
{[\mathbf{k g} / \mathbf{G J}]^{*}}\end{array}$ & $\begin{array}{c}\text { Emission } \\
\text { unit } \\
{[\mathbf{k g} / \text { year] }}\end{array}$ \\
\hline $\mathrm{SO}_{2}$ & 0.731 & 65.06 & 1.798 & 44.41 \\
\hline $\mathrm{NO}_{2}$ & 0.057 & 5.07 & 0.529 & 13.07 \\
\hline $\mathrm{CO}$ & 5.714 & 508.55 & 0.661 & 16.33 \\
\hline $\mathrm{CO}_{2}$ & 105.714 & 9408.55 & 290.851 & 7184.02 \\
\hline $\mathrm{Dust}$ & 2.057 & 183.07 & 0.106 & 2.62 \\
\hline $\mathrm{B}(\mathrm{a}) \mathrm{P}$ & 0.001 & 0.09 & $5.288 \cdot 10^{-5}$ & $1.3 \cdot 10^{-3}$ \\
\hline PAH & 0.286 & 25.45 & 0.033 & 0.82 \\
\hline * based on [31] & & & \\
\hline
\end{tabular}

\section{Conclusion}

A detailed interpretation of the geological profiles of the boreholes showed that relatively good thermal conditions of the rock mass occur in the area of Rabka-Zdrój. The average weighted thermal conduction coefficient ranges from 1.59 to $3.42[\mathrm{~W} /(\mathrm{m} \cdot \mathrm{K})]$, while the unit heat output ranges from $38.0-54.0[\mathrm{~W} / \mathrm{m}]$. The higher the unit heat output of the ground, the less deep the horizontal heat exchanger is. In the area of the Rabka-Zdrój boreholes, the prevailing layers of sandstones, shales, sandy gravels and clays were observed. The analysis shows that geothermal heat pump systems have significant potential for reducing low emission, especially in health resort areas, which are legally obliged to have healing properties of the climate. However, due to the common availability of a renewable heat source, which is the ground, these systems can be used in virtually every region of the world. In the case under consideration, the use of a ground source heat pump instead of a coal-fired boiler would contribute to the reduction of dust emissions and $\mathrm{B}(\mathrm{a}) \mathrm{P}$ in $99 \%$, as well as, in $97 \%$, for the reduction of $\mathrm{CO}_{2}$ and PAH. In the face of a significant problem of exceeding the permissible concentration standards of pollutants in Poland and the commonly occurring low emission (both in the agglomerations and in small villages), the necessary measures should be taken to reduce the amount of harmful substances emitted to the atmosphere.

The scientific work was financed from budgetary sources for years 2017-2021, as a research project under the "Diamentowy Grant" programme (grant agreement No DI2016 003946).

\section{References}

1. International Energy Agency, $\mathrm{CO}_{2}$ Emissions from Fuel Combustion (IEA, Paris, 2018) 
2. World Health Organization, Ambient air pollution: A global assessment of exposure and burden of disease (WHO Document production Service, Geneva, 2016)

3. European Environment Agency, Air quality in Europe - 2018 report, No. 12/2018 (Publication Office of the European Union, Luxembourg, 2018)

4. Ustawa o lecznictwie uzdrowiskowym, uzdrowiskach i obszarach ochrony uzdrowiskowej oraz o gminach uzdrowiskowych (Dz.U. 2017 poz. 1056)

5. X. Zhang, Q. Hu, J. of Earth Sci. 29, 2 (2018)

6. H. Zhao, Y. Gao, Z. Song, Strategic outlook of heat pump development in China Conference materials. Proceedings IEA Heat Pump Conference (2017)

7. Directive 2009/28/EC of the European Parliament and of the Council of 23 April 2009 on the promotion of the use of energy from renewable sources

8. J. W. Lund, D. H. Freeston, T. L. Boyd, Geothermics, 40 (2011)

9. J. W. Lund, Power Stations Using Locally Available Energy Sources (Springer, New York, 2018)

10. J. W. Lund, T. L. Boyd, Direct Utilization of Geothermal Energy 2015 Worldwide Review (Proceedings World Geothermal Congress, 2015)

11. P. Lachman, M. Burchat, Rynek pomp ciepla $w$ Polsce $w$ latach 2010-2017 Perspektywy rozwoju rynku pomp ciepła do 2030 roku (PORT PC, Kraków, 2018)

12. B. Porwisz, Szlakiem wód leczniczych i termalnych w Małopolsce (Wydawnictwo Kartograficzne „Compass”, Kraków, 2013)

13. M. Kuchcik, K. Błażejczyk, J. Szmyd, P. Milewski, A. Błażejczyk, J. Baranowski, Potencjat leczniczy klimatu Polski (Sedno Wyd. Akademickie, Warszawa, 2013)

14. H. Lorenc (ed.), Polish Climate Atlas (IMGW, Warszawa, 2005)

15. M. Kuchcik, K. Błażejczyk, Geographia Polonica 77, 1 (2004)

16. K. Żytko (ed.), Geological atlas of the western outer Carpathians and their foreland (Państ. Inst. Geol., Warszawa, 1988)

17. J. Boratyn, J. Lis, T. Malata, A. Pasieczna, R. Patorski, B. Radwanek-Bąk, A. Romanek, H. Tomassi-Morawiec, Objaśnienia do mapy geośrodowiskowej Polski 1:50 000 arkusz Rabka (Państw. Inst. Geol., Warszawa, 2004 )

18. B. Wiktorowicz, K. Karwacka, Biul. Państ. Inst. Geol. 436 (2009)

19. P. Kłapyta, Zeszyty Rabczańskie 3-4 (2015/2016)

20. Z. Paul, W. Ryłko, Objaśnienia do szczegółowej mapy geologicznej Polski 1:50 000 arkusz Rabka (Państw. Inst. Geol., Warszawa, 1987)

21. L. Rajchel, Geologia 35, 2/1 (2009)

22. J. Szewczyk, D. Gientka, Geol. Quart. 53, 1 (2009)

23. S. Plewa, Rozkład parametrów geotermalnych na obszarze Polski (CPPGSMiE PAN, Kraków, 1994)

24. J. Szewczyk, Przegląd Geol. 53,1 (2005)

25. K. Bryś, T. Bryś, M. A. Sayegh, H. Ojrzyńska, Energy and Buildings, 165 (2018)

26. W. Górecki (ed.), 2011 - Atlas zasobów wód $i$ energii geotermalnej Karpat Zachodnich ( AGH, Kraków, 2011)

27. M. Tyszer, B. Tomaszewska, Ciepłownictwo, Ogrzewnictwo, Wentylacja 47, 7 (2016) 
28. P. Lachman, A. Mirowski, A. Oczoś, A. Kaczmarczyk, M. Smuczyńska, M. Franke, S. Zbrojkiewicz, Wytycczne projektowania, wykonania i odbioru instalacji z pompami ciepła (PORT PC, Kraków, 2013)

29. Viessmann, Product card Vitocal 200-G (accessed 21.02.2019)

30. PORT PC, SCOP conversion from product card and manufacturer's declaration: http://portpc.pl/arkusze/ (accessed 21.02.209)

31. L. Pająk, Ciepłownictwo, Ogrzewnictwo, Wentylacja, 3 (2007)

32. M. Wiśniewska, Dokumentacja hydrogeologiczna ujęcia wody leczniczej z utworów trzeciorzędowych dla uzdrowiska Rabka-Zdrój (Narod. Arch. Geol. Państw. Inst. Geol., Warszawa, 1994)

33. Ustawa Prawo Geologiczne i Górnicze (Dz.U. 2017 poz. 2126) 